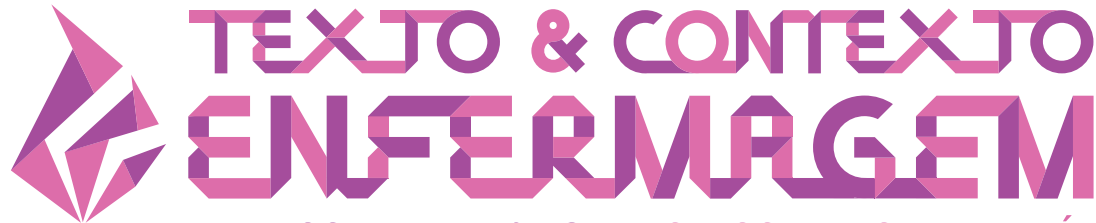

TEXT \& CONTEXT NURSING TEXTO \& CONTEXTO ENFERMERÍA

\section{NURSE'S MANAGEMENT OF WORKPLACE VIOLENCE SITUATIONS IN THE FAMILY HEALTH STRATEGY}

\author{
Helena Guimarães Flórido' \\ Sabrina da Costa Machado Duarte ${ }^{2}$ \\ Waleska Menengat Corrêa Floresta ${ }^{1}$ \\ Aline Miranda da Fonseca Marins ${ }^{2}$ \\ Priscilla Valladares Broca $^{2}$ \\ Juliana Rezende Montenegro Medeiros de Moraes ${ }^{2}$
}

${ }^{1}$ Secretaria Municipal de Saúde do Rio de Janeiro. Rio de Janeiro, Rio de Janeiro, Brasil. ${ }^{2}$ Universidade Federal do Rio de Janeiro. Rio de Janeiro, Rio de Janeiro, Brasil.

\begin{abstract}
Objectives: to identify situations of violence in the daily work of the health professionals of the Family Health Strategy and to describe the conducts adopted by these professionals in relation to the situations of violence identified.

Method: a qualitative, descriptive and exploratory study whose scenario was a Family Clinic of the city of Rio de Janeiro. Eighteen health professionals participated. Data was collected through semi-structured interviews and subjected to content analysis.

Results: three thematic categories emerged: Situations of workplace violence in the Family Health Strategy; Consequences of workplace violence on the Family Health Strategy; The nurse's role as leader of the Family Health Team and the strategies adopted in the face of workplace violence.

Conclusions: situations of interpersonal violence and collective violence were identified, exemplified by the contact with armed violence in the territory, racial discrimination, peer violence and violence suffered by the user, such as domestic violence, directly affecting the professional. The importance is highlighted of the nurse's role as leader of the Family Health Strategy team, envisioning the management of violence situations, often neglected.
\end{abstract}

DESCRIPTORS: Workplace violence. Primary health care. Family health. Health professionals. Nursing. Leadership. 


\section{GERENCIAMENTO DAS SITUAÇÕES DE VIOLÊNCIA NO TRABALHO NA ESTRATÉGIA DE SAÚDE DA FAMÍLIA PELO ENFERMEIRO}

\section{RESUMO}

Objetivos: identificar as situações de violência no cotidiano de trabalho dos profissionais de saúde da Estratégia de Saúde da Família e descrever as condutas adotadas por esses profissionais perante as situações de violência identificadas.

Método: estudo qualitativo, descritivo e exploratório cujo cenário foi uma Clínica da Família do município do Rio de Janeiro. Participaram 18 profissionais da saúde. Os dados foram coletados através de entrevistas semiestruturadas e submetidos à análise de conteúdo.

Resultados: emergiram três categorias temáticas: Situações de violência no trabalho na Estratégia de Saúde da Família; Consequências da violência no trabalho na Estratégia de Saúde da Família; Atuação do enfermeiro como líder da Equipe de Saúde da Família e as estratégias adotadas perante a violência no trabalho.

Conclusões: foram identificadas situações de violência interpessoal e a violência coletiva, exemplificadas pelo contato com a violência armada no território, discriminação racial, violência entre os pares e violência sofrida pelo usuário, como a violência doméstica, afetando diretamente o profissional. Destaca-se a importância da atuação do enfermeiro como líder da equipe da Estratégia de Saúde da Família vislumbrando o gerenciamento das situações de violência no trabalho, muitas vezes negligenciadas.

DESCRITORES: Violência no trabalho. Atenção primária à saúde. Saúde da família. Profissionais de saúde. Enfermagem. Liderança.

\section{MANEJO DE LAS SITUACIONES DE VIOLENCIA LABORAL POR PARTE DE LOS PROFESIONALES DE ENFERMERÍA EN LA ESTRATEGIA DE SALUD DE LA FAMILIA}

\section{RESUMEN}

Objetivos: identificar las situaciones de violencia en la rutina laboral de los profesionales de salud de la Estrategia de Salud de la Familia y describir las conductas que adoptan estos profesionales ante las situaciones de violencia identificadas.

Método: estudio cualitativo, descriptivo y exploratorio que tuvo como escenario a una Clínica de Salud Familiar del municipio de Río de Janeiro. Participaron 18 profesionales de la salud. Los datos se recolectaron a través de entrevistas semiestructuradas y se los sometió a análisis de contenido.

Resultados: surgieron tres categorías temáticas: Situaciones de violencia laboral en la Estrategia de Salud de la Familia; Consecuencias de la violencia laboral en la Estrategia de Salud de la Familia y Desempeño de los enfermeros como líderes de los equipos de Salud de la Familia y las estrategias adoptadas ante la violencia laboral.

Conclusiones: se identificaron situaciones de violencia interpersonal y colectiva, ejemplificadas por el contacto con la violencia armada en el campo de acción, discriminación racial, violencia entre pares y violencia sufrida por el usuario, como ser la violencia doméstica, que afecta directamente al profesional. Se destaca la importancia del desempeño de los enfermeros como líderes de los equipos de la Estrategia de Salud de la Familia, con vistas a manejar las situaciones de violencia laboral, muchas veces desatendidas.

DESCRIPTORES: Violencia laboral. Atención primaria de la salud. Salud de la familia. Profesionales de la salud. Enfermería. Liderazgo. 


\section{INTRODUCTION}

The Unified Health System (Sistema Único de Saúde, SUS), considering the bases provided for in the 1988 Constitution, predicts decentralized health actions and services, organized in a regionalized and hierarchical network with democratic and participative management aimed at achieving comprehensive care and equity in access. From this perspective, Primary Health Care or Primary Care (PC) should play a central role in the care network organization. ${ }^{1}$

Considering the National Policy of Primary Care, the terms Primary Care and Primary Health Care can be used as synonyms. In this study the term Primary Care (PC) was chosen, according to the current national policy. ${ }^{2}$

PC has "strengthened itself as a national policy from the 96 Basic Operating Standard (Norma Operacional Básica 96, NOB 96) of the Unified Health System, which established per capita transfers for PC and specific incentives for the implementation of Family Health Programs and community agents in the municipalities". 1:30 The NPPC enabled the Municipal Health Departments, through federal resources, to expand the coverage in access to health actions, which influenced the reorganization of the Brazilian health care model, culminating in the establishment of the Family Health Strategy (FHS). ${ }^{1}$

The NPPC has in the FHS the priority strategy for expansion and consolidation of PC, based on the principles of universality, equity and integrality, as well as guidelines of regionalization and hierarchy, territorial coverage and admission, considering the population enrolled needs, person-centered care, resoluteness through a clinic capable of building positive links and clinically and health-effective interventions, longitudinality and care coordination, network ordering, and community participation. ${ }^{2}$

The FHS teams are multi-professional and aim to favor the reorientation of work process, increasing resoluteness, affecting the health of people and the community, in order to provide costeffectiveness. They should be composed of doctors, nurses, nursing assistants or technicians, Community Health Agents (CHAs), dental surgeons and Oral Health assistants or technicians. There is a 40-hour weekly workload requirement for all team members. Thus, the FHS professionals should be linked to only one Family Health team, which, in the city of Rio de Janeiro, operates in Family Clinics (FCs). ${ }^{2-3}$

Among the attributions of the FHS teams, the following stand out: identification of the epidemiological and sociodemographic reality of the families assigned; addressing obstacles to referral and counter-referral; promotion of health education and self-care of individuals; and encouraging cross-sectorial actions to address identified problems. Among the advances obtained by the FHS, the following are highlighted: reduction in child mortality, expansion of health actions in municipalities with low Human Development Index (HDI), increase in health surveillance actions, and establishment of links between the population and the team's health professionals. ${ }^{2}$

The implementation of the FHS has privileged areas of greater risk and social vulnerability, providing health services to poor and extremely poor population groups in line with the principle of equity. The health units were inserted in a scenario of prevalence of social inequalities and violence, where there is the use of weapons and firearms, the consumption and market of narcotics and homicides.

In this context, the serious political and economic crisis experienced in Rio de Janeiro is highlighted, which directly interferes with the various segments related to health, education and safety. Many health professionals working in the FHS perform their work activities in areas of armed conflict, being exposed to various types of violence, which directly or indirectly affects the physical and mental integrity of professionals.

Violence is characterized by intentional acts aimed at harming oneself, others or a group, which may involve the use of physical force and/or power relations. Violence may result in physical harm such as reduced mobility or autonomy of the victim due to physical injury; psychological damage such 
as low self-esteem and anxiety; and social damages, such as interpersonal difficulties, academic and labor losses. The omission of situations of violence can be characterized as negligence. ${ }^{4}$

Violence at the workplace is defined as "any action, incident or behavior based on the offender's voluntary conduct, as a result of which a professional is assaulted, threatened, or otherwise harmed or injured while performing, or as a direct result of your job" 5:1 It may vary according to the level of development of each country; however, it usually occurs worldwide and can be aggravated by poverty, subjecting professionals to unacceptable situations. ${ }^{6}$

This type of violence demonstrates the degradation of the working conditions and of productivity, exposing workers to accidents and illness risks, and may include the relationship with the bosses, among peers and with the clients, characterized by incidents such as abuse, threats or attacks in work circumstances. Violence manifestations are configured as explicit or implicit harms to worker's safety, welfare or health. ${ }^{7}$

In the FHS, workplace violence can also be related to the multiple existing professional categories and the different levels of educational background, which contribute to bullying situations, often imperceptible at first.

Workplace violence directly interferes with the workers' health and the health professionals' practiced care, especially by nursing professionals, who are often prevented from crossing the territory and suffer directly from aggression by the population. Noteworthy is the significant increase in discussions about workplace violence at international level. ${ }^{8}$ However, it is necessary to invest in notifications, as well as studies on the subject in Brazil, observing the specificities of the current scenario. ${ }^{9}$

Considering the above, this study aims to identify situations of violence in the daily work of health professionals of the Family Health Strategy and to describe the conducts adopted by these professionals in relation to situations of identified violence.

\section{METHOD}

A qualitative, descriptive and exploratory study, with the scenario of a Family Clinic located in the Programmatic Area 3.1 of the city of Rio de Janeiro, chosen because it is located in a risk area, with constant reports by the professionals on violence in daily work. This $\mathrm{FC}$ is a professional training center, functioning as a practical field for the development of Nursing Residency and Family Health Medical Residency Programs.

The study participants were 18 health professionals, of both genders, victims of violence who worked in the four most vulnerable teams of the referred FC, selected according to the following inclusion criteria: working in the FC for more than six months, and acting in the teams of the territory areas considered most vulnerable. The exclusion criteria were not attending work during the data collection period and being away for vacation and various leave. Only 01 professional gave up participating claiming unavailability due to labor activity.

Data collection was performed from October to December 2016, through semi-structured interviews, with the help of a script containing the following questions: What were the situations of workplace violence that you have experienced in the FHS? How do these situations influence your personal and work life? What are the conducts of the FHS team in situations of workplace violence? What strategies are or could be adopted to minimize situations of violence? The participants were characterized according to the variables of gender, age, time in the scenario and professional function performed.

The interviews were conducted by the responsible researcher, lasting approximately 30 minutes each, in a quiet and private place in the institution, according to the participants' availability. All the interviews were recorded with an electronic recorder and later transcribed. Prior to the interviews, the 
participants received information about the objectives of the study and signed the Free and Informed Consent Form. Anonymity was granted to the participants and a codename was used based on the order of the interviews. Data collection reached the saturation point in interview No.13, and five interviews were added, equivalent to one third of the sample, which allowed the theoretical saturation closure to be safely reached..$^{10-11}$

Data analysis was performed using the Content Analysis methodology, ${ }^{12}$ which comprises the following phases: pre-analysis; content exploration; treatment of results, inference and interpretation, from where three categories emerged: Situations of workplace violence in the Family Health Strategy; Consequences of workplace violence on the Family Health Strategy; The nurse's role as leader of the Family Health Team and the strategies adopted in the face of workplace violence.

This study followed all the recommendations of Resolution No. 466/12 of the National Health Council (CNS/MS) for research with human beings.

\section{RESULTS}

\section{Characterization of the study participants}

Eighteen health professionals participated in the study, in which $56 \%$ were male, $50 \%$ were between 31 and 40 years old and $60 \%$ having worked in the FHS for up to 05 (five) years. Regarding the professional category, 39\% were Community Health Agents (CHAs), 23\% nurses, 17\% doctors, $11 \%$ nursing technicians, $5 \%$ dentists, $5 \%$ oral health assistants.

\section{Situations of workplace violence in the Family Health Strategy}

The study participants reported different situations of violence, which are external to the Family Clinic, conflict situations and armed violence in the territory.

Violence is often urban, shootings, clashes between police and traffickers, in which we stand in between of these clashes (E13).

When we are going to do home visits, we come across some situations, not of explicit, physical violence, but armed people selling drugs, as well as shootings (E2).

One time I was talking to a user and a bullet artifact hit a column and hit two palms above my head, just as she pulled me into her house. Unfortunately, it is inserted in our daily lives; we have to try to react (E17).

Violence caused by the clients, such as racial discrimination, verbal and physical aggression, was exemplified through the reports.

One registrant said that just because she was black, she couldn't do her job properly, and that offended me, because l'm black too (E15).

Situations that the user, even for lack of access in other services, arrives at the host and verbally assaults the person who is hosting, which is usually the CHA (E4).

Physical violence has already occurred with a CHA in the reception. The registrant took the child's vaccine card and slapped my colleague in the face (E15).

Violence among peers (professionals themselves), such as 'indifference' by the CHAs by the leadership and discrimination as to the social origin, was also identified.

I get very angry when there is indifference with the CHAs, you being threatened during the home visit by a person with a gun in hand, it's something serious. She spoke at a team meeting, once, twice, three times, they listened and no one said anything, no one took action (E6).

The problem is that when we tell a problem we had in the territory they think we are telling for fear. But this is our reality and some professionals even make fun of us (E13). 
Contact with the violence suffered by the users under care, such as domestic violence and violation of citizens' rights, has an impact on the professionals.

I went on a home visit and there were many kids playing on the street, the doctor talking to the kids, 'by this time of the day and these kids are here on the street', they were playing in the dump. At this time, the neighbor scolded the doctor and informed her not to scold the children because they are going through great suffering, a family problem. Because the brother had his father killed because he was sexually abusing his younger sister, and afraid that the sisters would tell at school, he dropped them out of school and so they were not studying (E14).

Every day we deal with patients who suffer the stress of violence and attend to a second comorbidity, with the issue of background violence. We ask for the parameters to know if we are controlling a blood pressure well, for example. People who are stressed, worried about their children, about the family that may be involved in trafficking, and this may be causing their blood pressure to rise (E9).

\section{Consequences of workplace violence on the Family Health Strategy}

Impairments in user follow-up due to violence in the territory were identified, as reported by the participants.

The day I was in a confrontational situation in the territory, everything was very quiet, we were working normally and within seconds, there was a shooting. Broadly, this has been affecting our way of working (E13).

We would need at least two shifts of HV [Home Visit] in the week for territory diagnosis, so you see the most vulnerable areas, then you can detect those patients who have a hard time coming to the clinic, so your job is not just in here in the clinic, and that is when violence harms (E1).

The professionals who live and work in the same territory are the most vulnerable to situations of violence.

I find the issue of the agents very difficult, just because they live there, they think they are used to violence; I talk about the preceptors and nurses, because they think they are used to it, so they let it go (E6).

And we, especially the CHAs, cannot file a report because people know that we are going to visit the houses and we are from the area. We live in the area. We know what the right thing to do is, which was to report, but we cannot do it right because there is the parallel power involved (E14).

The feelings of fear, frustration, apathy, 'feeling of powerlessness' and vulnerability, as well as the psychological distress of the professionals experiencing situations such as exposure to armed conflict, drug and gun trafficking and professional burnout, were frequently reported by the respondents:

I feel apathetic because there is an area to work with, people to attend to and we have no security to work. In addition, we have no logistical support (E13).

Many times I feel bad, afraid, feeling frustrated, apprehensive, because it is momentary, in the case of shootings, there is no time, no day, it is something momentary. So, by not knowing what might happen at the moment, we get worried, we don't have a right place to run and it can cause the worst (E15).

It makes me very tense, makes me anguished, brings fear, insecurity to go to the street. Many times, I don't want to go back, I don't want to go back often because I'm afraid. This affects me a lot, brings discouragement, anguish, a huge stress and sometimes it is very difficult to keep up with the work (E18). 


\section{The nurse's role as leader of the Family Health Team and the strategies adopted in relation to workplace violence}

The interviewees highlighted the nurse as the most mobilized professional of the FHS health team for the management and leadership in situations of violence, acting as a mediator, coordinator, facilitator and articulator of actions and activities.

In my team, we try to inform our superior, the nurse, when there is violence with any team member (E15).

If either for some reason we can't come down, from lunchtime or when we have to go down to the clinic to start or finish the workday, because of shootings in the area, we warn it. And this is communicated to the direct supervisor, the nurses, who report it to management (E18).

As a team reference, I try to understand what is going on and thus minimize the situation damage. I try to get the person out of focus, for example, is having a conflict in the host area, user and CHA, or I take out the CHA or I take the user out the place and try to understand what caused the situation (E1).

Regarding the strategies adopted for managing situations of violence, training was highlighted, such as the 'Safer Access to Essential Public Services' program.

'Safe Access' is a tactic to prevent us from staying in the area at the time of armed conflicts, and it is necessary to classify the territory as green, yellow or red, it is a 'Safe Access' strategy (E1).

When the area turns yellow by 'Safe Access', the team members stay in the clinic doing internal work, not going to the territory (E3).

The investment in communication through mobile devices and apps among professionals and users to acknowledge reports of violence was also cited.

One informs the other, makes phone calls, it is a team agreement to know where a shooting going on and should not go to protect themselves. We always carry the phone, we talk to everyone, we have information from wherever we are (E18).

We have a radio for communication called NUDEC [Núcleo de Defesa Civil (Civil Defense Center)] who works with Civil Defense, and we exchange information with it, knowing if he can work within the area or not (E17).

The reorganization of the home visits during armed conflicts in the community, the search for shelter in safe places and the support of the professionals for conflict management were reported by the participants.

When we go to the street, we always go in pairs or more to make it easier, because sometimes, something one person doesn't see in the area, the other can see it. Mostly, somewhere to hide, because that's the routine, we go out with the sight of somewhere to hide and run down the place (E18).

During the home visits, there are some conducts such as lowering the windows and entering slowly blinking, which we kind of accept, because nobody has a steel chest, but we do not have much to do, especially when we are in the territory (E7).

The respondents reported notification and discussion of situations of violence in the team meetings.

We have to investigate, go after it, take it to the management to make a notification about work, what the labor law rules say. Searching for the management and filling out the violence notification form, whatever it is (E3).

Trying to talk with team members when a violent situation occurs to try to calm and resolve the current and future situation (E2). 
The adoption of personal strategies to reduce the stress experienced, such as a search for leisure activities, attachment to religion, spending time with family and friends, is one of the main strategies adopted when facing workplace violence situations.

We have tried some alternative measures. I play video games at home. When I get home, especially after something that messes with me, I play video games (E13).

In these situations, I cling to religion and ask God a lot to help me day after day, because it is not easy. You are afraid of going up and that may occur again and come across the same situation. I always try to think that one day may be better than the other (E16).

\section{DISCUSSION}

The workplace violence situations identified in this study are characterized as interpersonal violence and collective violence, resulting in physical, psychological and social harm. Identifying and differentiating the types of violence contributes to the planning and development of preventive and victim care actions. ${ }^{4,6}$

Interpersonal violence refers to intentional aggressions against another individual, such as intrafamily violence and community violence, present in the interviewees' statements. Intra-family violence is characterized by intentional actions against family members, which can be physical, psychological, sexual or negligent aggressions that retard or interrupt victims' physical and psychosocial development. Community violence involves individuals who live in the same community context but who do not always know each other. It usually occurs in public spaces, involving physical aggression, sexual violence, damage to public assets and other forms of aggression aimed at causing intentional harm. ${ }^{4,6}$

The results also demonstrated collective violence occurrence, which can be subdivided into social violence, such as terrorist actions and religious intolerance related crimes; political violence related to civil wars; and economic violence, characterized by slave labor and exploitation of the labor force. ${ }^{4}$

The professionals who experience violence may suffer from decreased work performance and satisfaction, as well as from increased apprehension about similar situations, which negatively affects their physical and mental health, especially during the first two years after the violent incident. ${ }^{13}$ Violence at work can cause time off work, work overload and professional exhaustion, and interfere with patient safety, increasing error rates and other occurrences.

With regard to the health professionals, workplace violence directly affects their quality of life, as these professionals work directly with people (users) who have severe and complex problems, ${ }^{14}$ being prevented from performing their work duties due to armed violence in territory and the impossibility of denouncing the situations experienced. The results showed that many professionals live and work in the same territory, being more vulnerable to situations of violence.

This greater vulnerability is related to the feelings of fear, frustration and apathy mentioned by the interviewees. It is noteworthy that the CHAs and the nursing staff are the most susceptible professionals to be victims of violence, considering the characteristics of the profession, such as the type of work performed, proximity to users and territory. ${ }^{8,9,15}$ The CHAs and nursing professionals act directly performing functions outside the FC, such as HVs and active search, being subjected to threats when addressing some common social problems in territory, including the use of illicit substances and domestic violence.

The user is the biggest perpetrator of violence against the health professionals, usually practicing verbal violence, followed by physical violence..$^{9,14-15}$ The scenario is closely related to the situations of violence.

A study conducted in Spain highlighted that Primary Health Care concentrates the highest number of cases of workplace violence (53.9\% of the cases), in which out of 10 cases of aggression 
seven were caused by users. However, the true magnitude of violence is silenced by low notification rates, present not only in European countries, but also in other continents. ${ }^{16}$

Violence can be understood as the product of human interactions that are established in a precarious and turbulent work scenario or as a form of manifestation of the discontent of those involved (workers and users) with the precariousness to which they are exposed, as identified in study scenario. ${ }^{9}$

Workplace violence is also exerted by the peers themselves, that is, health professionals who occupy similar or superior positions hierarchically, and related to precariousness and to the health crisis. Aggressive behaviors are now interpreted as expressions of discontent and indifference to the precarious situation experienced, which can be considered a neglect of the essential conditions of worker dignity as a representative of the health system in front of the population. ${ }^{9}$

Thus, the professionals working in the public health system have a higher risk of exposure to peer violence, which may be related to the employment stability of the server, enabling violence situation without the risk of job loss. Thus, the aggressions are interpreted by the professionals as a response to the organizational values that worship virility as a value and consequently deny weakness and fear in the face of precarious working conditions and the relationships established in the workplace. ${ }^{9}$

It is worth highlighting the heterogeneity of the interviewed group, which presents different ages, genders, times and types of professional training. The heterogeneous group is more susceptible to conflicts and opinion divergence, especially when exposed to stressful situations such as workplace violence.

The results of this study highlighted the importance of the nurse's role as leader of the FHS team acting in conflict mediation, coordination, reorganization of proposed activities, training with emphasis on effective communication strategies, notification of violence situations and support from other professionals of the FHS team. The leadership exercised by nurses in the complex scenario of the FHS emerges naturally, and may be a natural individual characteristic and/or learned during professional training, as well as practiced daily in the exercise of labor activities. In this sense, the nurse demonstrates protagonism in conducting and directing the team management processes and their interpersonal relationships.

Corroborating with the results presented, a study conducted in the city of Santa Catarina highlighted the importance of trust between the professionals and the community in generating bonds for exercising leadership. It is essential that nurses develop a reliable relationship with their team, which will facilitate leadership and the flow of actions, making work more meaningful and increasing professionals' commitment with users. As for the negative aspects that interfere with leadership, we can mention the unsatisfactory working conditions associated with the workplace and with violence in the territory. ${ }^{17}$

Leadership is an important management tool, as the leader exercises power over the team to achieve the proposed objectives and to make strategic decisions. The leader's power is active and legitimately exercised as the group meets the expectations. In addition to the management aspect, leadership is an adjunct to the entire work process of nurses, considering the spheres of the agents (workers), the people (object - individuals, biological body, family, collectivity and work team), the instruments (material and cognitive tools) and the purposes (various conceptual and methodological plans). ${ }^{18}$

Regarding PC, nursing leadership is considered a fundamental axis, assuming a strategic role in crisis situations that affect social and health policies, according to the currently reality experienced in city of Rio de Janeiro. Globally, nurses have the capacity to intervene in favor of health promotion, in the development of collective and individual educational practices, community mobilization and comprehensive care. ${ }^{18}$ 
Through leadership, nurses can also advocate strategies for coping with violence, such as training through the 'Safer Access to Essential Public Services', encouraging the reporting of violence situations, encouraging stress relief measures and seeking effective communication. ${ }^{19}$

'Safer Access to Essential Public Services' was a methodology developed to prevent and mitigate risks of security incidents in public facilities such as schools, hospitals and Social Assistance Reference Centers (SARCs), considering the concerns arising from the increase of armed violence and its humanitarian consequences. Among the program's objectives, the following stand out: protect lives; promote safe environments and strengthen professionals and institutions resilience; develop risk and crisis management strategies; promote changes in the behavior, knowledge and posture of professionals and managers; improve overall service efficiency by optimizing human and financial resources use; and expand access to essential public services. ${ }^{19}$

The FHS professionals trained in the 'Safer Access to Essential Public Services' methodology develop risk assessment attitudes with a consequent adoption of the prevention strategies, thus enabling greater security for the team in the face of conflicts in the conflicted territories.

Encouraging the reporting of situations of violence can be advocated through the search for effective communication as a strategy for managing violence. A situation analysis should be established by listening, which is related to leadership, negotiation and cultural analysis. The results of the study demonstrated the need for listening and understanding the professionals affected by violence, since the situations are often overlooked by the peers, which is also characterized as a situation of violence for the professionals.

"The importance of the notifications is the possibility of breaking the violence cycle and guaranteeing protection to the victims through the action of the protection agencies. In addition, reporting enables mapping the prevalence and characteristics of the violence situations, which can be used in proposing prevention and intervention policies". 4:32-33 Depending on the type of violence and age, different government agencies may be triggered and the Notification Grievance Information System (Sistema de Informação de Agravos de Notificação, SINAN) is a national system responsible for collecting epidemiological data for mandatory notifications. However, collective violence is not notified by the SINAN.

Regarding the incentive to stress relief measures, the interviewees highlighted the importance of family life and leisure and relaxation activities. In this context, it is up to the health facility managers to define clear strategies for stress reduction through the pursuit of workplace wellness programs, for example, support of relaxation techniques, ${ }^{20}$ talking in group about the situations experienced and mutual support. It is important that the professionals feel welcomed when facing everyday violence, which will significantly improve the quality of life at work.

As a study limitation, it is highlighted that data collection was performed only in a single work context, i.e., only in a Unit of the Family Health Strategy from the municipality of Rio de Janeiro. Considering that workplace violence is present in other scenarios and countries with similar working conditions, the results of this paper may boost new research, allowing a better understanding of the phenomenon investigated: workplace violence of the health professionals. Follow-up studies are suggested to evaluate intervention strategies and prevention of violence in the health context, considering multidisciplinary team's leadership, management and decision-making.

It is believed that this study may lead to further research on the subject, in addition to encouraging the professionals to notify the violence situations experienced and to discuss in a sensitive and effective manner about such occurrences in the workplace. 


\section{CONCLUSION}

This study aimed to identify violence situations in daily work of the health professionals of the Family Health Strategy and to describe the conducts adopted by these professionals in relation to the situations of violence identified.

Regarding the situations of workplace violence, it was possible to identify interpersonal and collective violence, exemplified by everyday situations, such as contact with armed violence in the territory, racial discrimination, violence between peers and contact with violence suffered by the user, like domestic violence. All situations of violence affect the professionals causing damage at work, as well as physical and psychological disorders, permeated by feelings of apathy, anxiety and vulnerability.

This research contributed to the analysis of the phenomenon of violence at work in the FHS, which has often been neglected, not addressed, untreated and not prevented. Thus, the importance of the role of the nurse as the FHS team leader is emphasized, envisaging the encouragement of the team, the notification of the situations of violence often neglected and the support in the strategies to reduce stress in the workplace.

\section{REFERENCES}

1. Mendonça MHM, Matta GC, Gondim R, Giovanella L. Os desafios urgentes e atuais da atenção primária à saúde no Brasil. In: Mendonça MHM, Matta GC, Gondim R, Giovanella L. Atenção primária à saúde no Brasil: conceitos, práticas e pesquisa. Rio de Janeiro, RJ(BR): Editora Fiocruz, 2018; p.29-47.

2. Ministério da Saúde (BR). Portaria n. 2.436, de 21 de setembro de 2017. Aprova a Política Nacional de Atenção Básica, estabelecendo a revisão de diretrizes para a organização da Atenção Básica, no âmbito do Sistema Único de Saúde (SUS). [Internet]. 2017 [cited 2018 Aug 19]. Available from: http://bvsms.saude.gov.br/bvs/saudelegis/gm/2017/prt2436_22_09_2017.html

3. Secretaria Municipal de Saúde, Rio de Janeiro, RJ(BR). Unidades de Saúde. Clínicas da Família. [cited 2018 Sept 28]. Available from: http://www.rio.rj.gov.br/web/sms/clinicas-da-familia

4. Habigzang LF, editor. Manual de capacitação profissional para atendimentos em situações de violência [Internet]. Porto Alegre, RS(BR): PUCRS [Internet]; 2018 [cited 2018 Sept 19]. Available from: http://editora.pucrs.br/livro/manual-de-capacitacao-profissional-para-atendimentos-emsituacoes-de-violencia/assets/livro-completo.pdf

5. International Labour Organizational. Joint programme launches new initiative against workplace violence in the health sector. [Internet]. 2008 [cited 2018 Sept 19]. Available from: https://www. ilo.org/global/about-the-ilo/newsroom/news/wcms_007817/lang--en/index.htm

6. International Labour Organizational. Violence at work. World of work [Internet]. 2018 [cited 2018 Sept 28];Spe Issue. Available from: https://www.ilo.org/wcmsp5/groups/public/---dgreports/--dcomm/documents/publication/wcms_630276.pdf

7. Organización Internacional del Trabajo. Consejo Internacional de Enfermeras. Organización Mundial de la Salud. Internacional de Servicios Públicos. Programa conjunto sobre la violencia laboral en el sector de la salud. Directrices marco para afrontar la violencia laboral en el sector de la salud [Internet]. 2002 [cited 2018 Sept 28]. Available from: http://apps.who.int/iris/bitstream/ handle/10665/44072/9223134463_spa.pdf?sequence=1

8. Palma A, Ansoleaga E, Ahumada M. Violencia laboral en trabajadores del sector salud: revisión sistemática. Rev Med Chile [Internet]. 2018 [cited 2018 Sept 27];146:213-22. Available from: https://scielo.conicyt.cl/pdf/rmc/v146n2/0034-9887-rmc-146-02-0213.pdf 
9. Dal Pai D, Sturbelle ICS, Santos C, Tavares JP, Lautert L. Physical and psychological violence in the workplace of healthcare professionals. Texto Contexto Enferm [Internet]. 2018 [cited 2018 Sept 27];27(1):e2420016. Available from: https://dx.doi.org/10.1590/0104-07072018002420016

10. Rhiry-Cherques RH. Saturação em pesquisa qualitativa: estimativa empírica de dimensionamento. Af-Rev PMKT [Internet]. 2009 [cited 2018 Oct 10];4(8):20-7. Available from: http://www.revistapmkt. com.br/portals/9/edicoes/revista_pmkt_003_02.pdf

11. Nascimento LCN, Souza TV, Oliveira ICS, Moraes JRMM, Aguiar RCB, Silva LF. Theorical saturation in qualitative research: na experience report in interview with schoolchildren. Rev Bras Enferm [Internet]. 2018 [cited 2018 Sept 27];71(1):243-8. Available from: http://dx.doi. org/10.1590/0034-7167-2016-0616

12. Bardin L. Análise de Conteúdo. São Paulo, SP(BR): Edições 70; 2011.

13. Johansen IH, Baste V, Rosta J, Aasland OG, Morken T. Changes in prevalence of workplace violence against doctors in all medical specialties in Norway between 1993 and 2014: a repeated cross-sectional survey. BMJ Open [Internet]. 2017 [cited 2018 Sept 27];7:e017757. Available from: http://dx.doi.org/10.1136/bmjopen-2017-017757].

14. Nowrouzi-Kia B. The impact of workplace violence on health care workers' quality of life. Dev Med Child Neurol [Internet]. 2017 Jul [cited 2018 Sept 27];59(7):675. Available from: http://dx.doi. org/10.1111/dmcn.13466.

15. Fisekovic Kremic MB, Terzic-Supic ZJ, Santric-Milicevic MM, Trajkovic GZ. Encouraging employees to report verbal violence in primary health care in Serbia: a cross-sectional study. Zdr Varst [Internet]. 2017 [cited 2018 Sept 19];56(1):11-7. Available from: http://dx.doi.org/10.1515/sjph2017-0002

16. The National Observatory of Aggressions to Physicians (ONAM). Workgroup and General Council of Official Medical Associations of Spain (CGCOM). BMC Res Notes [Internet]. 2018. [cited 2018 Sept 19];11:347. Available from: http://dx.doi.org/10.1186/s13104-018-3393-7

17. Lanzoni GMM, Meirelles BHS, Cummings G. Nurse leadership practices in primary health care: a grounded theory. Texto Contexto Enferm [Internet]. 2016 [cited 2018 Sept 26]; 25(4):e4190015. Available from: http://dx.doi.org/10.1590/0104-07072016004190015

18. David HMSL, Acioli S, Seidlr HM, Brandão PS. O enfermeiro na atenção básica: processo de trabalho, práticas de saúde e desafios contemporâneos. In: Mendonça MHM, Matta GC, Gondim $\mathrm{R}$, Giovanella L. Atenção primária à saúde no Brasil: conceitos, práticas e pesquisa. Rio de Janeiro, RJ(BR): Editora Fiocruz; 2018. p. 337-67.

19. Comitê Internacional da Cruz Vermelha. Acesso Mais Seguro para Serviços Públicos Essenciais [Internet]. 2018. [cited 2018 Sept 27]. Available from: https://www.icrc.org/pt/publication/acessomais-seguro-para-servicos-publicos-essenciais-brasil

20. Starc J. stress factors among nurses at the primary and secondary level of public sector health care: the case of Slovenia. Open Access Maced J Med Sci [Internet]. 2018 Feb 15 [cited 2018 Sept 28];6(2):416-22. Available from: http://dx.doi.org/10.3889/oamjms.2018.100 


\section{NOTES}

\section{ORIGIN OF THE ARTICLE}

Extracted from Family Health Nursing Residency Course Completion Paper entitled Violence in the routine of the professionals of the Family Health Strategy, presented to the Family Health Nursing Residency Program, linked to the Graduate Program from the Escola de Enfermagem Anna Nery, Universidade Federal do Rio de Janeiro, in 2017.

\section{CONTRIBUTION OF AUTHORITY}

Study Desing: Duarte SCM, Florido HG, Floresta WMC.

Data collection: Florido HG, Floresta WMC.

Analysis and interpretation of data: Duarte SCM, Florido HG, Floresta WMC.

Discussion of the results: Duarte SCM, Florido HG, Floresta WMC, Marins AMF, Broca PV, Moraes JRMM.

Writing and/or critical review of content: Duarte SCM, Florido HG, Floresta WMC, Marins AMF, Broca PV, Moraes JRMM.

Review and final approval of the final version: Duarte SCM, Florido HG, Floresta WMC, Marins AMF, Broca PV, Moraes JRMM.

\section{ETHICS COMMITTEE IN RESEARCH}

Approved by the Ethics Committee in Research with Human Beings Escola de Enfermagem Anna Nery I Hospital Escola São Francisco de Assis / Universidade Federal do Rio de Janeiro, under opinion No. 1635.345 and CAAE 56945416.1.0000.5238, and of the Municipal Health Secretariat of Rio de Janeiro, according to Opinion No. 1678654 and CAAE 56945416.1.3001.5279.

\section{CONFLICT OF INTERESTS}

There is no conflict of interest.

\section{HISTORICAL}

Received: November 16, 2018

Approved: March 25, 2019

\section{CORRESPONDING AUTHOR}

Sabrina da Costa Machado Duarte sabrina.cmduarte@gmail.com 